\title{
Conceptualizing Corporate Sustainability Reporting and Risk Management Towards Green Growth in the Malaysian Oil and Gas Industry
}

\author{
Fong-Woon Lai ${ }^{1}$, Muhammad Kashif Shad ${ }^{2}$, Syed Quaid Ali Shah ${ }^{3}$ \\ 1,2,3 Management \& Humanities Department, Universiti Teknologi PETRONAS, Malaysia \\ Corresponding Author: Email: mkashifshad@gmail.com*
}

\begin{abstract}
Recently, there have been many reports of catastrophic accidents in the oil and gas $(\mathrm{O} \& \mathrm{G})$ industry which led to huge financial losses and hazards to humans and the environment. Apart from the primary operational (technical) risks, there exist numerous non-technical risk factors such as workforce protection, climate change, ecosystem, biodiversity, health and safety, governing compliance, and other environmental, and social issues. These risks if left without intervention could affect the green growth and eco-friendly resilience of the O\&G companies. Thus, this work offers a conceptual framework on how corporate sustainability practices along with risk management implementation are stimulating green growth in the O\&G industry. The presented theoretical and conceptual framework underpinned by the stakeholder theory proposed in this paper provides a foundation for empirical validation of the intertwined relationship between the pertinent variables. The measurement of the variables such as corporate sustainability performance, enterprise risk management and green growth is proposed to be drawn from earlier research and developed frameworks and guidelines by prominent organizations. The significance of this paper is to lend guidance to Malaysian oil and gas players to embrace green growth through sustainability and risk management implementation.
\end{abstract}

\section{Keywords-Sustainability Reporting, Risk Management, Green Growth, Oil and Gas, Conceptual Framework.}

\section{Introduction}

In the current era, large corporations are looking for new ways to reduce their risks by implementing enterprise risk management (ERM) and sustainability agenda. ERM implementation has long been seen by corporations as a source of managing financial, strategic, compliance and operational risks. Nevertheless, in recent years myriad of new risks surrounding the organizations have arisen resulting in the expansion of corporate risk management boundaries. For instance, The Global Risks Report 2016) issued by the World Economic Forum stated that topmost risks faced by the organizations are related to the workplace, geopolitical, social, climate change, environmental, health, and safety risks (non-technical risks). Likewise, the World Business Council for Sustainable Development (WBCSD), advocates on the transition of global risks from a focus on an economic risk towards non-technical risks noted as societal, geopolitical and environmental risks (WBCSD, 2017). In line with that large corporations are continuously developing appropriate frameworks that implement strategic opportunities to establish risk management initiatives to safeguard not only the economy but also the society as well as the environment (Shah et al., 2021). Also, the organizations are being held liable and responsible by regulatory bodies for their economic, environmental and social impact, therefore forcing risk and sustainability management as critical components in their business pursuit (Jagoda \& Wojcik, 2019). Although governments and policymakers advocate for effective risk and sustainability management implementation for sustainable development and green growth, the impacts of such initiatives are still at the infancy stage. Particularly, academic research studies on ERM and sustainability practices towards green growth specifically in the O\&G industry not evident so far. Thus, this study aims to conceptualize 
ERM and corporate sustainability reporting model for its multiplying effect towards green growth in Malaysian O\&G industry.

Malaysian $O \& G$ industry is proposed as our research sample due to the following rationales. Firstly, O\&G firms in Malaysia are significant and crucial due to its pivotal role in economic development of the nation. Its crude oil production as of May $2019^{1}$ is approximately 668.13 $\mathrm{BBL} / \mathrm{D} / 1 \mathrm{~K}$. Being a second major exporter of the region, it yields $20 \%$ to $30 \%$ of Malaysia's GDP (Govt., 2017). Therefore, Malaysia's O\&G industry works as a backbone and a core sector of growth for the country. Secondly, not only the O\&G industry is an important sectors but it is also the riskiest industry (Capital and labor-intensive, high risk, high reward) in the global economy (Foo, Jamal, Karim, \& Ulum, 2015). Its operations have both positive and negative effects on the triple bottom line performance that trigger stakeholders to incur superfluous risk (George, SitiNabiha, Jalaludin, \& Abdalla, 2016); (Shad \& Lai, 2019). For instance, in April 2010 the Gulf of Mexico failure was the most destructive oil spill in the calendar of United States (US) caused by classic failure of leadership and management at BP. This incident was considered as the biggest catastrophes in the O\&G history impacting local economies, businesses, sensitive coastlines, marine life, wildlife, and human communities. The US federal government estimated that 397.7 million dollars of oil were spilled, and it affected over 16,000 miles' coastline. Eleven workers were deceased, and 4.9 million barrels of oil were spilled into the Gulf of Mexico. The blowout of oil killed over 8,000 animals in just six months. Other than that, the wild spread and dangerous consequences in this industry lead to pollution, an increase of greenhouse effect, acid rain, poor water quality, groundwater pollution, and biodiversity loss, etc. This indicates that tragedies in the O\&G industry could have catastrophic effects on organizations itself, the economy, the social community, and the environment. As such, the existing qualms concerning the implementation of risk management for non-technical risks, coupled with the publication of sustainability reporting in relation to the efficacy of the ERM implementation for green growth and resilience in the O\&G industry, are the primary inspiration for the current study. Therefore, this study proposed examination of the ERM implementation and sustainability performance using the globally recognized framework for $\mathrm{O} \& \mathrm{G}$ companies, namely, International Petroleum Industry Environmental Conservation Association's (IPIECA) 2015 guidelines and their contribution to sustainable development using green growth framework proposed by the Organization for Economic Co-operation and Development (OECD) that foster the essential plans for innovations, investment, and conditions that increase the modern bases for financial development and advancement.

\section{Literature Review}

Green growth has become a global concern due to energy resources depletion, environmental degradation and climate change (Wang, Sun, \& Guo, 2019). The recent study by Hajar et al. (2020) defined green growth as "a low-carbon, climate-compatible development centered around growing the economy while improving the wellbeing of the society, the environment, and the ecosystem". The concept of green growth emerged internationally in 2012 at the United Nations Conference established in Brazil particularly on Sustainable Development (UNCSD) to overcome the growing ecological hazard caused by economic operations around the globe. The UN conference members, however, realized the need of converting world's financial growth into greener one (Lin \& Zhu, 2019). To cushion the society and ecological nature and obtain green growth, the governments and regulatory bodies normally articulate various tools and initiatives. Inevitably, enterprise risk management (ERM) and corporate sustainability management directly affect the operational and production decision in an organization and leads to sustainable development and green growth. Corporate sustainability reporting (CSR) and ERM have been

\footnotetext{
${ }^{1}$ https://tradingeconomics.com/malaysia/crude-oil-production Accessed on $15^{\text {th }}$ October 2019.
} 
tested from various viewpoints such as; from its implementation to achievement of firm's business objectives, green growth, corporate social and environmental performance and enhancement of overall business performance etc. (Jagoda \& Wojcik, 2019).

Corporate sustainability is the influence of organisation's current action on the future economic system, society and natural environment and its integration in firm's strategic planning is important (Ameer \& Othman, 2012). It has been unveiled in a survey by PwC that corporate Malaysia has steep a steep curve in educating sustainability vis-à-vis at its early stage with low maturity in coping sustainability risk factors. The respect for and well-being of ecosystems (Environment) and people (Social) is the foundation for the sustainability value set. It is evident from literature that ecological degradation resume to denigrate the oil production. The arrangement of sustainability workshops and programs in O\&G industry mostly enhance the ecosystem, low carbon economy and living conditions in the region. Moreover, the ignorance of sustainability issues can be very damaging to society which may also result in environmental degradation as well as unexpected financial losses (Jan et al., 2021). Generally, it is widely accepted by regulators, consultants and corporate leaders that business success in the 21 st century will be defined by more than just financial profit whereby strong expectations are developed for companies to strengthen their involvement in strong sustainability practices that covers three key areas, namely environment, social and governance (ESG).

On the other hand, ERM is an organized approach in overcoming the mismatch among organizations' strategy, procedures, workers, machinery, and expertise to estimate and control the risks associated with operations in a particular organization (Lai \& Shad, 2017); (Shad \& Lai, 2015c). Practically speaking about the recent changes in the environment, new laws, geopolitical risks, legislation, and increasing investor demands persuade corporations to adopt an efficacious and useful risk management approach (Shad, Lai, Fatt, Klemeš, \& Bokhari, 2019); (McShane, 2018). A firm with risk management framework signals that related and relevant risks are recognized, understood and therefore, prioritized. The information gathered regarding the rising risks from an active ERM might be used in decision making of investment plans, budgeting and performance evaluations. The execution of appropriate risk management offers a platform to manage organisation's eccentric risks other than systematic (Lai, Shad, \& Khan, 2017). Furthermore, firm's competitive advantage can be enjoyed specifically when alignment of the risk management practices is done to its core goals and overall strategy (Lai \& Shad, 2017); (Shad \& Lai, 2015b). According to Tasmin and Muazu (2017) ERM is deemed as pertinent to achieve sustainable competitive advantage and higher business performance. It also helps the O\&G industry to achieve operational excellence and improve productivity (Tasmin, Muazu, Aziati, \& Zohadi, 2020). The operational excellence in return leads to create sustainable improvement and assists in productive assets and capital utilization, environmental protection as well as create value to all relevant stakeholders. The recent study by Sun, Bi, and Yin (2020) stated that green growth is a high-risk activity that can be protected through proper risk management implementation.

Hence, this study is urged whether risk management implementation and sustainability practices in managing non-technical risks (environment, regulation, safety or society) are helpful and impacts on economic value and green growth of the oil and gas listed companies in Malaysia. Empirical literature indicated that the role of ERM and CSR is to minimize the conflicts among various stakeholders and to be accountable and responsible towards businesses, society and environment for ethical outcomes, less risky corporate behavior and stable growth (Jagoda \& Wojcik, 2019). The review of the literature also revealed that ERM and CSR practices maximize value for all stakeholders and ultimately enhance overall firm performance. For instance, Yilmaz and Flouris (2010), proposed a conceptual framework for integrating the concepts of ERM and corporate sustainability. The authors considered ERM and corporate sustainability as the explicit organizational tool that creates economic, social and environmental awareness along with management and integration of corporate strategies in achieving economic performance. Mark and 
Showalter (2015), postulated that sustainability and ERM have supported the organizations to watch over the risk factors that can affect their strategic objectives. Moreover, the authors stated that the ultimate objective of both sustainability and ERM in an organization is to help increases long-term feasibility through efficient identification and management of organizational risks. Although, several studies related to ERM, firm performance and sustainability reporting exist. But still research lacks in providing a vibrant insight of the combined effect of CSR, ERM implementation and green growth relationship (Farrell \& Gallagher, 2019). Hence, in this paper, we take a step farther and conceptualize a framework that will provide an opportunity to integrate ERM implementation and CSR towards green growth in the context of Malaysian O\&G industry.

\section{THEORETICAL FRAMEWORK}

The essence of stakeholder theory is adopted to support this research. The emphasis of the stakeholder theory is explicitly on the equilibrium of stakeholders' interests (Klimczak, 2007). Based on the stakeholder theory, within the organizations, apart from shareholders and investors, there are various stakeholders involved such as creditors, suppliers, customers, local community (Freeman, 2010). The notion of the stakeholder suggests that the aforementioned stakeholders might be curious in knowing the firm's operations and objectives (Aziz, Manab, \& Othman, 2015). Hence, these stakeholders expect the reporting of what organizations do, and they believe it as their right in knowing the company's information. In short, this theory changes the focus of company strategies from only considering shareholders to some external stakeholders. The relevance of stakeholder theory is instituted with the notion of risk management, sustainability disclosure, and CSR practices, therefore, it covers overall prospect of sustainability and its relationship with firm value (Wheeler, Colbert, \& Freeman, 2003). The stakeholder theory supports the value maximization notion of sustainability reporting and suggested a positive nexus of sustainability reporting with a company's accounting performance (Donaldson \& Preston, 1995). By employing stakeholders theory Weng, Chen, and Chen (2015) found a significant and positive effect of various stakeholders such as competitors, governments and employees on green innovation practices of the companies which ultimately influence overall environmental and financial performance. Therefore, firm's value is dependent upon the good relationships of the firm with its various stakeholders. The satisfaction of various stakeholders improves the corporate image, which ultimately increases the firm value. Thus, with the support of the stakeholder theory, the study hypothesized that efficient ERM and sustainability practices increases the value of the firm. Enterprise risk management deals with a myriad of risks facing the organization in an integrated way. A firm with strong governance and ERM implementation is certainly crucial in ever sphere of society. In case of limited resources, it is the governance and efficient implementation of risk management to meet the expectation of people by overcoming the cost linked to external debt and agency costs that can help to raise organization's value (Aras, Tezcan, \& Kutlu Furtuna, 2018; Klimczak, 2007). To sum up, the stakeholder theory supports the protection and improvement in corporate reporting practices, implementation of holistic risk management, sustainability practices to manage the conflicting interests of different stakeholders. In this regard, the risk management and corporate sustainability practices represent their responsibility towards different stakeholder groups by protecting economic, environmental and social risks and supporting the legitimate interests through transparent and improved corporate disclosures practices (Orazalin, Mahmood, \& Narbaev, 2019).

\section{CONCEPTUAL FRAMEWORK}

Considering extensive review of the literature regarding ERM implementation and corporate sustainability reporting that affect enhancing green growth, the current paper developed a conceptual framework see Figure 1. Based on the figure it is shown that how intertwined relationship of corporate sustainability reporting practices and enterprise risk management 
implementation connects with green growth. The conceptual framework assumes that by having a solid ERM framework and practicing of strong sustainability activates, the O\&G companies may significantly contribute to the green growth and sustainable development.

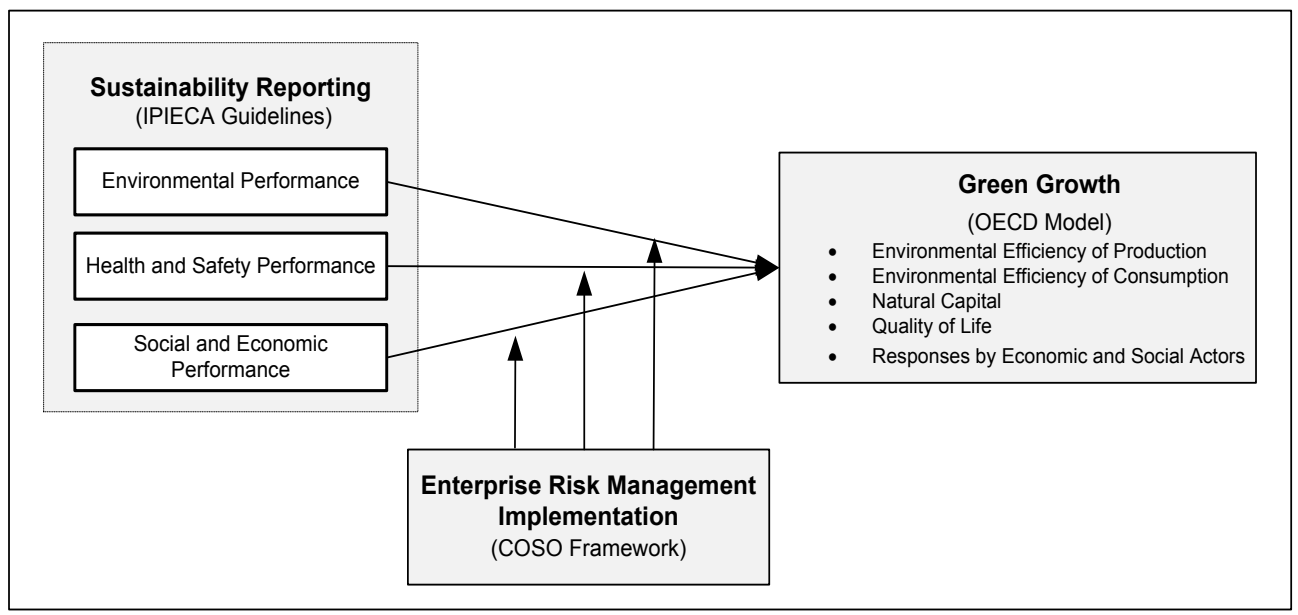

Figure 1: The Conceptual Framework

\section{Research Context and Variables Explanation}

\subsection{Malaysian Oil and Gas Industry}

The oil and gas industry as an important player in the global economy fuel the sustainable and green future of any country. Malaysia is one of the most dynamic owners of oil and gas reserves and the third-largest exporter around the globe in terms of liquefied natural gas and the secondlargest oil and gas producer following Indonesia in the region (US, 2017). In 2016, Malaysia was at $25^{\text {th }}$ placing of the oil-producing countries in the world. In 2015, Malaysian O\&G sector contributes about $22 \%$ in government revenue. Despite of global dispute on oil prices, O\&G sector remained crucial to the country. It speeds up the country economic structure and consequently emerge it as a vibrant economy. The largest Malaysian national oil and gas company PETRONAS now international oil and gas company is playing a critical role in the development of Malaysia. Successfully, it enters into the world's 500 companies (Tasmin et al., 2020) and its shares are traded among Bursa Malaysia top gainers. Due to an integral part of O\&G sector in the country economy, its drive towards sustainable development can pave a way to economic growth, ecological enhancement and societal well-being of the country. The disclosure of sustainability practices by Malaysian O\&G companies is voluntary and are at initial stages in managing and diminishing sustainability risks (Shad, Lai, Shamim, \& Khan, 2018). Therefore, this work adopted renowned sustainability frameworks such as IPIECA (2015) to foster the green growth framework proposed by OECD.

\subsection{Corporate Sustainability Reporting}

Sustainability reporting practices are aimed to convey the knowledge of triple bottom line performance and are important as a combined response to continuous growth and sustainable development (Shortall, Davidsdottir, \& Axelsson, 2015). Furthermore, the legislative requirements are also being placed on the businesses to incorporate sustainability into their core business activities and operations. To achieve sustainability, the organizations are required to 
change their industrial operational process, utilization of their resources, waste treatment practices as well as emission control process in the manufacturing (Abubakar, 2014). At national level of Malaysia, Bursa Malaysia designed several guidelines regarding sustainability operations to every sector. At the international level, several sustainability reporting guidelines and frameworks are issued by various organizations around the world, such as Global Reporting Initiative (GRI), Commission for Sustainable Development (CSD) and IPIECA. IPIECA as a standardized framework is specifically designed for the O\&G industry that provides guidance on sustainability matters among O\&G companies. First IPIECA guidelines were issued in 2002, and later updated in 2011 and the latest update was made in 2015. This framework is globally recognized as the most widely used framework in the O\&G sector. Thus, IPIECA framework's indicators are directly related to the oil and gas companies. According to Shortall et al. (2015), appropriate indicators are essential to measure the sustainability practices of the organizations. Therefore, in this paper, our sustainability efforts are guided by the IPIECA framework that defines the areas where the O\&G industry have to play a role in managing risks and their impacts. The adopted framework classified the sustainability reporting indicators into three main dimensions, including environmental performance dimension, health and safety performance dimension and social and economic performance dimension. Each of these three dimensions includes several sub-dimensions and these sub-dimensions are operationalized by several items, comprising a total of 34 items see Table 1 . The first dimension refers to the environment, which comprises three sub-dimensions namely; climate change and energy, ecosystem services, and local environmental impact. These three sub-dimensions are operationalized by eleven (11) items. The second dimension is health and safety, which is divided into three sub-dimensions such as; health and environmental risks, workforce protection, and process safety and asset integrity. These three sub-dimensions are operationalized by five (5) items. The last dimension refers to social and economic issues, which comprise five sub-dimensions such as; community and society, human rights, local content, business ethics and transparency, and labor practices. These sub-dimensions are further operationalized by eighteen (18) items. This study proposed the 2015 edition of IPIECA's reporting guidelines to inspect the sustainability reporting of Malaysian O\&G companies.

Table 1: IPIECA Sustainability Indicators for the Oil and Gas Industry

\begin{tabular}{|l|c|l|}
\hline \multicolumn{3}{|c|}{ Oil and Gas Industry Sustainability Reporting Guidance (IPIECA) } \\
\hline \multicolumn{3}{|c|}{ Environmental indicators } \\
\hline \multirow{4}{*}{ Indicators } & E1 & Greenhouse gas emissions \\
\cline { 2 - 3 } Climate Change and Energy & E2 & Energy use \\
\cline { 2 - 3 } & E3 & Alternative energy sources \\
\cline { 2 - 3 } & E4 & Flared gas \\
\hline Biodiversity and Ecosystem Services & E5 & Biodiversity and ecosystem services \\
\hline \multirow{2}{*}{ Water } & E6 & Freshwater \\
\hline \multirow{4}{*}{ Local Environmental Impact } & E7 & Discharges to water \\
\hline \multirow{2}{*}{ Health and Safety } & E8 & Other air emissions \\
\hline & E9 & Spills to the environment \\
\cline { 2 - 3 } & E10 & Waste \\
\cline { 2 - 3 } & E11 & Decommissioning \\
\hline \multirow{2}{*}{ Workforce Protection } & HS1 & Workforce participation \\
\cline { 2 - 3 } & HS2 & Workforce health \\
\cline { 2 - 3 } & HS3 & Occupational injury and illness incidents \\
\hline Product Safety, Health, and Environmental Risks & HS4 & Product stewardship \\
\hline Process Safety and Asset Integrity & HS5 & Process safety \\
\hline
\end{tabular}




\begin{tabular}{|l|c|l|}
\hline \multicolumn{3}{|c|}{ Social and Economic Indicators } \\
\hline \multirow{4}{*}{ Community and Society } & SE1 & Local community impact and engagement \\
\cline { 2 - 4 } & SE2 & Indigenous peoples \\
\cline { 2 - 4 } & SE3 & Involuntary resettlement \\
\cline { 2 - 4 } & SE4 & Social investment \\
\hline \multirow{4}{*}{ Local content } & SE5 & Local content practices \\
\cline { 2 - 4 } & SE6 & Local hiring practices \\
\cline { 2 - 3 } & SE7 & Local procurement and supplier development \\
\hline \multirow{4}{*}{ Business Ethics and Transparency } & SE8 & Human rights due diligence \\
\cline { 2 - 4 } & SE9 & Human rights and suppliers \\
\cline { 2 - 4 } & SE10 & Security and human rights \\
\hline \multirow{4}{*}{ Labor Practices } & SE11 & Preventing corruption \\
\cline { 2 - 3 } & SE12 & Preventing corruption involving business partners \\
\cline { 2 - 4 } & SE13 & Transparency of payments to host governments \\
\cline { 2 - 3 } & SE14 & Public advocacy and lobbying \\
\hline & SE15 & Workforce diversity and inclusion \\
\cline { 2 - 3 } & SE16 & Workforce engagement \\
\cline { 2 - 3 } & SE17 & Workforce training and development \\
\cline { 2 - 3 } & SE18 & Non-retaliation and grievance system \\
\hline
\end{tabular}

\subsection{Risk Management Implementation}

Increasing sustainability issues as a consequence of O\&G companies' operations has led to advance research on risk management programs (Shad \& Lai, 2019). An effective risk management framework provides a practical reference point to those responsible for planning, developing, operating, and regulating the best way to apply risk management in the business activities for protecting the environment and efficiently allocating resources. Although different frameworks and guidelines are available for extending the notion of risk management, but the findings revealed in the "2008 enterprise risk management (ERM) Benchmarking Survey" lead by the "Institute of Internal Auditors (IIAs) and IIA Research Foundation's Global Audit Information Network" proposed that "The Committee of Sponsoring Organisations of the Treadway Commission" (COSO) ERM Framework has widely been incorporated to ease corporations in their ERM processes. In one survey, it has been identified that COSO framework remains among worlds' top ten books in terms of risk management and extensively read by researchers. Similarly, the 2004 guidelines produced by COSO have been considered the worldbest template in exercising the ERM (Power, 2009). Of late, in September 2017, the COSO issued an updated ERM framework, labeled as "Enterprise Risk Management - Integrating with Strategy and Performance" to assist the top governance in knowing and preferring of uncertainties faced by the firm and evaluate the risks' short and long term effect on business performance (COSO, 2017). This work recommends the measurement of ERM using the guidelines and dimensions demonstrated in the COSO, 2017 integrated framework. The 2004 COSO's ERM framework is comprised of three dimensions, which constitutes 1) Objectives (including strategic, operations, reporting and compliance), 2) Components (including eight components/ areas) and 3) levels of the organization (including business unit or subsidiary level). The eight components of "2004 COSO ERM" framework are: "1) internal environment, 2) objective setting, 3) event identification, 4) risk assessment, 5) risk response, 6) control activities, 7) information and communication, and 8) monitoring". These components contribute equally in the process of ERM Implementation. In parallel to evidence reflected by prior studies that ERM foster the firm value by mitigating volatility, cost of capital, provide handsome returns and improve efficiency (Zou, Isa, \& Rahman, 2017); (Shad \& Lai, 2015a). Therefore, this research aims to evaluate how ERM adds value to business vis-à-vis green growth of Malaysian O\&G companies. 


\subsection{Green Growth}

Green growth, also known as environmentally sustainable economic growth, perform a pivitol role specifically in the present time of ecological crisis and resource dwindling (Kim, Kim, \& Chae, 2014). Heading towards green growth demonstrates outlining a pathway to achieve economic and financial success by using fewer resources and fewer emissions in the atmosphere where the wellbeing relies on. The indicators of green growth are significant to assess and monitor the practices performed by firms to obtain green growth. OECD acknowledged the essence of green growth and devised a framework to foster the requirements for innovation, investment and conditions that in turn push the additional resources of economic growth (Abdullah, Jali, \& Ibrahim, 2017). Since, OECD is a standardized and comprehensive framework that is designed to reflect green growth notion, hence we choose it as a framework that will assist us in finding the green growth of the Malaysian oil and gas companies. The OECD framework is a novel tool that measures the sound outcomes of green growth practices and provides knowledge regarding country economic plans. According to Kim et al. (2014), indicators proposed by OECD are appropriate for comparative analysis of green growth at national and global level. The OECD framework is comprised of three main dimensions that include; (1) economic activities (production, consumption, trade), (2) natural capital and environment and (3) economic and social agents. These three dimensions are further classified into five interrelated measurement indicators namely, "(1) indicators of environmental efficiency of production and changes in production patterns, (2) indicators of environmental efficiency of consumption and changes in consumption patterns, (3) indicators describing the natural asset base, (4) indicators monitoring the environmental dimension of quality of life, (5) indicators describing policy responses and economic opportunities, socio-economic context and characteristics of growth" (Kim et al., 2014),(OECD, 2017). Furthermore, these five measurement indicators will be operationalized by twelve items designed by the OECD framework for green growth strategies see Figure 2.

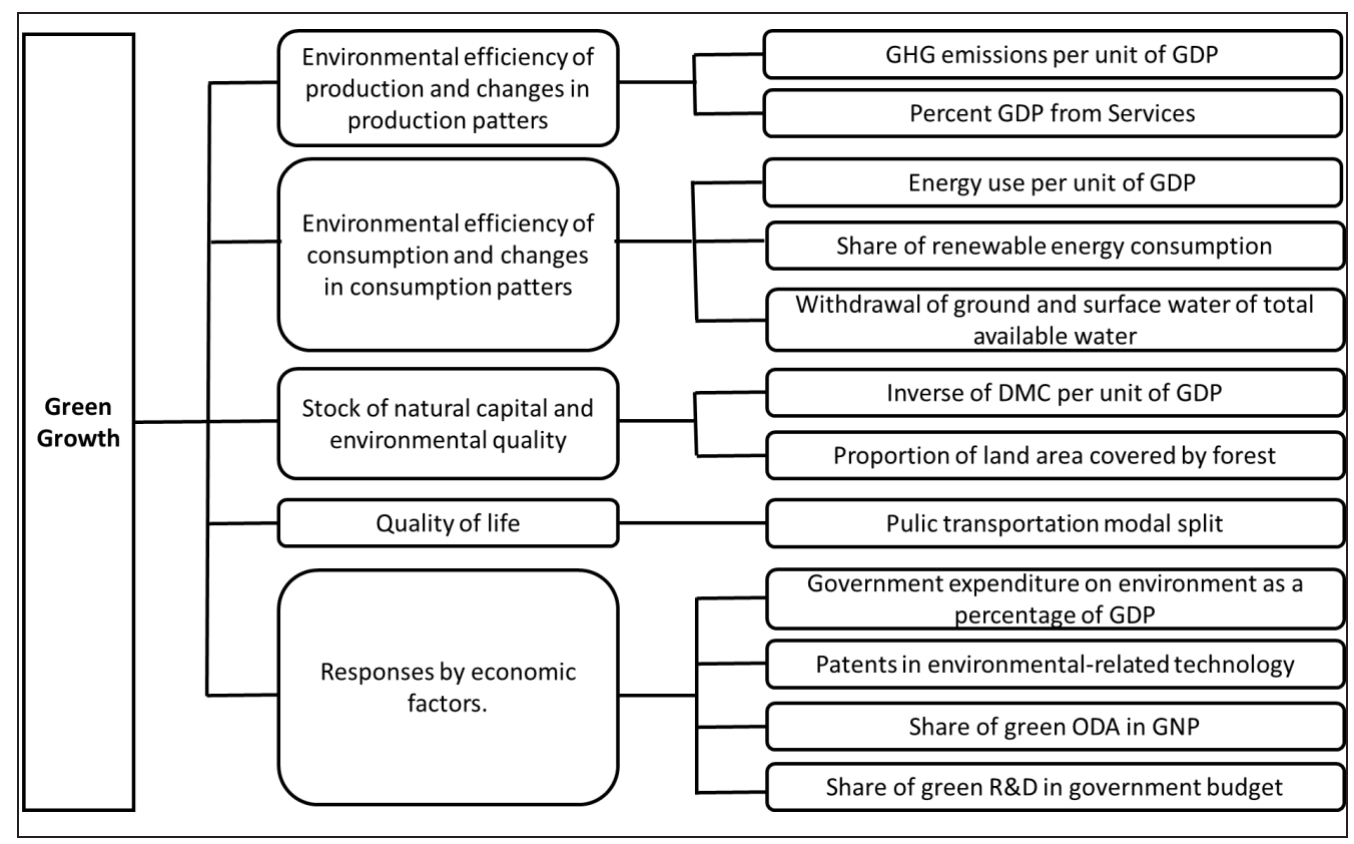

Figure. 2: Green Growth Framework and Measurement Indicators (adopted from Kim et al. (2014)) 


\section{Discussion}

This study necessitated due to the emergence of a myriad of new risks in the oil and gas industry and their catastrophic impact which led to the huge economic losses and hazards to the human and the environment. It would lead to water scarcity, environmental pollution, biodiversity and change in the climate driving to unsustainable economic growth and development (Kasztelan, 2017). The literature reveals that the emergence of new risks such as social and environmental risk, and compliance requirement in organizations demand enhancement in governance practices and implementation of an effective risk management framework especially in the energy sector (Soomro \& Lai, 2017); (Shad et al., 2019). Many O\&G firms are reframing their operations by increasing awareness among the stakeholders about the organizations' exposure, scarce resources, greenhouse gasses, consumption of energy through sustainability management and efficient implementation of risk management strategies to achieve greener growth (Tasmin et al., 2020); (Saardchom, 2013). Green growth and environmental protection are at the forefront of oil and gas companies and for that most of these companies are developing economic, environmental and social strategies to reduce risk. Moreover, green growth is of great significance to achieve sustainable development goals (SDG's) (Lin \& Zhu, 2019). The operations of O\&G sector usually have dual, positive-negative, impact on wide areas which are essential for achieving the SDGs such as community and ecosystem. The Malaysian's oil and gas industry forms a backbone and is a crucial for economy and it can be the main actor to achieve sustainability agenda as well as the persuasion of green growth by strengthening risk management, sustainability, and environmental regulatory frameworks. The oil and gas companies have implemented dynamic risk management processes which thrive on the mitigations of all pertinent risks. According to Jagoda and Wojcik (2019) risk management aims at averting predictable events and is thus, an invaluable strategic objective that improves product quality and lower production cost, which in turn makes growth resources efficient, cleaner and more resilient. Many O\&G companies are also investing in sustainability plans that aim at reducing the risks associated with triple bottom line. Furthermore, such investment by $\mathrm{O} \& \mathrm{G}$ companies will not only mitigate economic risk but also has positive influence on the other two mains layer, society-environment, of sustainability. As sustainability practices increases the green initiatives take priorities. Therefore, oil and gas companies find it necessary to incorporate risk management and sustainability practices into their corporate strategies for green growth and sustainable future. The conceptualization of risk management and sustainability practices presented in this paper can help organization can design their process models that align with the long-term goals of balancing sustainable development issues and low economic disruptions.

\section{Conclusion}

The present work alludes a conceptual design that reflects the intertwined relationship of effective ERM implementation and corporate sustainability reporting with green growth. Prior studies albeit limited indicated that ERM and sustainability disclosure in organizations enhance firm performance and promote competitiveness. Anticipated results of suggested framework will offer significant repercussions to the theory as well as practice. Firstly, this paper establishes a theoretical foundation for risk management implementation and corporate sustainability reporting incorporating non-technical risks and its value implication in terms of green growth generation. Secondly, this study proposed an index based on the COSO ERM framework to measure risk management implementation and sustainability disclosure practices index through the recently published guidance by IPIECA to measure sustainability management activities by Malaysian O\&G companies. Thirdly, this study attempts to close the knowledge gap by proposing a model incorporating risk management and sustainability management ensuring the environmental and social security and decarbonization, green growth, and resilience among the oil and gas sector. Practically the significance of this study is that its findings can be used as references to further enhance the regulators' policy documents (i.e. Securities Commission, Bursa Malaysia, and PETRONAS which has the regulatory mandate for upstream O\&G 
activities) for the O\&G public listed companies' with respect to their sustainability management compliance requirements and strategies on the environment, social and governance (ESG). Specifically, the findings can supplement and complement Strategy Paper 11 (Climate-resilient development) and Strategy Paper 12 (Growth through sustainable use of natural resources) of the Eleventh Malaysia Plan (11th MP). This, in turn, shall augur well with the government's objective to strengthen the resilience of Corporate Malaysia against climate change and natural disaster in line with the aspiration of the Strategic Thrusts of the 11th MP to pursue green growth. Furthermore, it will support the national government in attainment of their set goals of making Malaysia a sustainable advance economy with low carbon and socially inclusive manner. Also, this work will provide inputs to corporate Malaysia (O\&G public listed companies) on best practices of risk management and sustainability performance which will ensure green growth through environmental and resource productivity, natural asset base, environmental quality of life, and economic opportunities and policy responses on the reduction of energy consumption, reduce GHG emissions, and environmental deterioration by the oil and gas companies. Moreover, the proposed framework will serve as a benchmark and valuation framework on corporate paper by corporate rating agencies such as Rating Agency Malaysia (RAM).

\section{Acknowledgments}

The researchers would like to acknowledge Yayasan Universiti Teknologi PETRONAS (YUTP) for funding this research grant under Cost Center: 015LCO-188, Management and Humanities Department, Universiti Teknologi PETRONAS and Center of Social Innovation (CoSI) for the support to conduct this research.

\section{REFERENCES}

Abdullah, H., Jali, M. R. M., \& Ibrahim, F. W. (2017). The current state of Malaysia's journey towards a green economy: The perceptions of the companies on environmental efficiency and sustainability. International Journal of Energy Economics and Policy, 7(1), 253-258.

Abubakar, T. (2014). A Study of Sustainability in the Oil and Gas Supply Chain. (PhD). University of Central Lancashire,

Ameer, R., \& Othman, R. (2012). Sustainability practices and corporate financial performance: A study based on the top global corporations. Journal of business ethics, 108(1), 61-79.

Aras, G., Tezcan, N., \& Kutlu Furtuna, O. (2018). Multidimensional comprehensive corporate sustainability performance evaluation model: Evidence from an emerging market banking sector. Journal of Cleaner Production, 185, 600-609. doi:https://doi.org/10.1016/j.jclepro.2018.01.175

Aziz, N. A. A., Manab, N. A., \& Othman, S. N. (2015). Exploring the perspectives of corporate governance and theories on sustainability risk management (SRM). Asian Economic and Financial Review, 5(10), 1148. doi:10.18488/journal.aefr/2015.5.10/102.10.1148.1158

COSO. (2017). Enterprise Risk Management Integrating with Strategy and Performance, available at: www.erm.coso.org. Retrieved from

Donaldson, T., \& Preston, L. E. (1995). The stakeholder theory of the corporation: Concepts, evidence, and implications. Academy of management Review, 20(1), 65-91.

Farrell, M., \& Gallagher, R. (2019). Moderating influences on the ERM maturity-performance relationship. Research in International Business and Finance, 47, 616-628. doi:https://doi.org/10.1016/j.ribaf.2018.10.005

Foo, V., Jamal, A. A. A., Karim, M. R. A., \& Ulum, Z. K. A. B. (2015). Capital structure and corporate performance: Panel evidence from oil and gas companies in Malaysia. International Journal of Business Management and Economic Research, 6(6), 371-379.

Freeman, R. E. (2010). Strategic management: A stakeholder approach: Cambridge University Press. New York, USA. 
George, R. A., Siti-Nabiha, A., Jalaludin, D., \& Abdalla, Y. A. (2016). Barriers to and enablers of sustainability integration in the performance management systems of an oil and gas company. Journal of Cleaner Production, 136, 197-212.

The Global Risks Report. (2016). Retrieved from World Economic Forum, Switzerland:

Govt., M. (2017). Malaysia - Oil and Gas. Available at https://www.export.gov/article?id=MalaysiaOil-and-Gas-Equipment.

Hajar, H. A. A., Tweissi, A., Hajar, Y. A. A., Al-Weshah, R., Shatanawi, K. M., Imam, R., . . Hajer, M. A. A. (2020). Assessment of the Municipal Solid Waste Management Sector Development in Jordan towards Green Growth by Sustainability Window Analysis. Journal of Cleaner Production, 120539.

Jagoda, K., \& Wojcik, P. (2019). Implementation of risk management and corporate sustainability in the Canadian oil and gas industry. Accounting Research Journal, 32(3), 381-398. doi:10.1108/ARJ05-2016-0053

Jan, A. A., Lai, F. W., Daraz, M. U., Tahir, M., Ali, S. E. A., Zahid, M., \& Shad, M. K. (2021). Integrating sustainability practices into islamic corporate governance for sustainable firm performance: from the lens of agency and stakeholder theories. Quality \& Quantity. doi:https://doi.org/10.1007/s11135-021-01261-0

Kasztelan, A. (2017). Green Growth, Green Economy and Sustainable Development: Terminological and Relational Discourse. Prague Economic Papers, 2017(4), 487-499.

Kim, S. E., Kim, H., \& Chae, Y. (2014). A new approach to measuring green growth: Application to the OECD and Korea. Futures, 63, 37-48.

Klimczak, K. M. (2007). Risk Management Theory: A comprehensive empirical assessment. Kozminski Working Paper No. 01-2007, 22.

Lai, F. W., \& Shad, M. K. (2017). Economic Value Added Analysis for Enterprise Risk Management. Global Business and Management Research, 9(1s), 338.

Lai, F. W., Shad, M. K., \& Khan, A. A. (2017). Value Creating Determinants Of Enterprise Risk Management And Its Economic Value Added. Paper presented at the IEBMC 2017 - 8th International Economics and Business Management Conference, Kuantan, Pahang, Malaysia.

Lin, B., \& Zhu, J. (2019). Fiscal spending and green economic growth: Evidence from China. Energy Economics, 83, 264-271.

Mark, B., \& Showalter, S. (2015). ERM and Sustainability: Togather on teh Road Ahead. Strategic Finance, 96(9), 32.

McShane, M. (2018). Enterprise risk management: History and a design-science proposal. The Journal of Risk Finance, 19(2), 137-153.

OECD. (2017). Green Growth Indicators 2017.

Orazalin, N., Mahmood, M., \& Narbaev, T. (2019). The impact of sustainability performance indicators on financial stability: evidence from the Russian oil and gas industry. Environmental Science and Pollution Research, 26(8), 8157-8168.

Power, M. (2009). The risk management of nothing. Accounting, organizations and society, 34(6), 849855.

Saardchom, N. (2013). Enterprise Risk Management under Sustainability Platform. Journal of Business and Economics, 4(1), 32-41.

Shad, M. K., \& Lai, F.-W. (2015a). A conceptual framework for enterprise risk management performance measure through economic value added. Global Business and Management Research, 7(2), 1.

Shad, M. K., \& Lai, F.-W. (2015b, April 23-24- 2015). Developing an Enterprise Risk Management Value Enhancing Model Manifested through Economic Value Added Analysis Paper presented at the WSEAS Applied Computer and Applied Computational Science (ACACOS '15), Kuala Lumpur, Malaysia. 
Shad, M. K., \& Lai, F.-W. (2015c). Enterprise Risk Management and Firm Performance Validated Through Economic Value Added Factors. International Journal of Economics and Statistics, 3, $148-154$.

Shad, M. K., \& Lai, F.-W. (2019). Enterprise Risk Management Implementation and Firm Performance: Evidence from the Malaysian Oil and Gas Industry. International Journal of Business and Management, 14(9).

Shad, M. K., Lai, F.-W., Fatt, C. L., Klemeš, J. J., \& Bokhari, A. (2019). Integrating sustainability reporting into enterprise risk management and its relationship with business performance: A conceptual framework. Journal of Cleaner Production, 208, 415-425.

Shad, M. K., Lai, F.-W., Shamim, A., \& Khan, A. A. (2018). Corporate Sustainability Reporting Practices in the Malaysian Oil and Gas Companies. Platform: A Journal of Management and Humanities, 1(1), 1-10.

Shah, S. Q. A., Lai, F.-W., Shad, M. K., Konečná, Z., Goni, F. A., Chofreh, A. G., \& Klemeš, J. J. (2021). The Inclusion of Intellectual Capital into the Green Board Committee to Enhance Firm Performance. Sustainability, 13(19), 10849. Retrieved from https://www.mdpi.com/2071$\underline{1050 / 13 / 19 / 10849}$

Shortall, R., Davidsdottir, B., \& Axelsson, G. (2015). Geothermal energy for sustainable development: A review of sustainability impacts and assessment frameworks. Renewable and sustainable energy reviews, 44, 391-406.

Soomro, M. A., \& Lai, F.-W. (2017). Examining A New Paradigm of Enterprise Sustainability Risk Management. Global Business \& Management Research, 9(1).

Sun, Y., Bi, K., \& Yin, S. (2020). Measuring and Integrating Risk Management into Green Innovation Practices for Green Manufacturing under the Global Value Chain. Sustainability, 12(2), 545.

Tasmin, R., \& Muazu, H. (2017). Moderating Effects of Risk Management Function on Determinants of Enterprise Risk Management Implementation in Malaysian Oil and Gas Sector: A Conceptual Framework. Journal of Technology Management and Business, 4(2).

Tasmin, R., Muazu, M., Aziati, A. N., \& Zohadi, N. (2020). The mediating effect of enterprise risk management implementation on operational excellence in the Malaysian oil and gas sector: a conceptual framework. Future Business Journal, 6(1), 1-6.

US. (2017). U.S. Energy Information Administration. Production of Crude Oil including Lease Condensate 2016. Retrieved 27 April 2018.

Wang, Y., Sun, X., \& Guo, X. (2019). Environmental regulation and green productivity growth: Empirical evidence on the Porter Hypothesis from OECD industrial sectors. Energy Policy, 132, 611-619.

WBCSD. (2017). Sustainability and Enterprise Risk Management: The First Step Towards Integration. Retrieved from Switzerland:

Weng, H.-H. R., Chen, J.-S., \& Chen, P.-C. (2015). Effects of green innovation on environmental and corporate performance: A stakeholder perspective. Sustainability, 7(5), 4997-5026.

Wheeler, D., Colbert, B., \& Freeman, R. E. (2003). Focusing on value: Reconciling corporate social responsibility, sustainability and a stakeholder approach in a network world. Journal of general management, 28(3), 1-28.

Yilmaz, A. K., \& Flouris, T. (2010). Managing corporate sustainability: Risk management process based perspective. African Journal of Business Management, 4(2), 162.

Zou, X., Isa, C. R., \& Rahman, M. (2017). Valuation of enterprise risk management in the manufacturing industry. Total Quality Management \& Business Excellence, 1-22. doi:10.1080/14783363.2017.1369877 